\title{
The Relationship between Students' Strengths in Multiple Intelligences and Their Achievement in Learning English Language
}

\author{
Majid Pour-Mohammadi* \\ Department of Language Translation, Islamic Azad University, Rasht, Iran \\ Email: pourmohammad@iaurasht.ac.ir \\ Mohamad Jafre Zainol Abidin \\ School of Educational Studies, University of Science Malaysia, Malaysia \\ Email: jafre@usm.my \\ Khairul Anuar Bin Yang Ahmad \\ School of Educational Studies, University of Science Malaysia, Malaysia \\ Email: tataeek@gmail.com
}

\begin{abstract}
This article reports the findings of a study conducted in an urban secondary school in Perak, Malaysia. This study is about the relationship between students' strengths in multiple intelligences and achievement in learning English. Multiple intelligences, proposed by Gardner (1983), look at the multiple cognitive capacities across human thinking. They include the verbal/linguistic, logical/mathematical, visual/spatial, bodily/kinesthetic, musical/rhythmic, interpersonal, intrapersonal and naturalistic intelligences. Findings from this study suggest that in a learning environment where multiple intelligences may not be actively used, there is a tendency to have weak and negative correlation between multiple intelligences and English language achievement. Yet, there are distinct differences in the relationship between the two streams of Science and Art regarding the subjects they take. Practical implications for these findings recommend that teachers ought to exploit multiple intelligences in the teaching and learning processes to provide opportunities for the students to enhance their multiple intelligences.
\end{abstract}

Index Terms - multiple intelligence, English language achievement, instructional strategy

\section{INTRODUCTION}

Gardner (1983) proposed that ' $\ldots$ there is not just one form of cognition which cuts across all human thinking. There are multiple intelligences with autonomous intelligences capacities.' It has since attracted a lot of attention in the field of education as it affects how learning takes place within the individual and its implication on teaching. Students have the capacity to progress in all of the intelligences provided that they are given the opportunity to activate them. This is the responsibility of the teachers as educators. If not most practitioners would agree that 'one size does not fit all'. This view concurs with Ebeling (2000) who said that teachers should expect that some students could not learn what has been taught because of their diversity of needs. A factor like this should be taken seriously in improving their achievement in the language. Invariably though, they will excel more in some of the intelligences than the others.

Gardner (1983) suggested that our instructional methods must undergo a revolution if we are to reach all students who have at least eight ways of knowing. This revolution must start with awareness of both learners and practitioners on the issue. The teacher has the key to unlock the learners' full potential by designing classroom activities to develop all of their multiple intelligences (Lazear, 1994). Once student adapts at using his intelligences effectively through practice and exposure, then learning can easily be an independent venture.

The innovative approach to the teaching of the English language has also affected the Malaysian education system. Multiple intelligences as a pedagogical consideration was first introduced into the Malaysian Smart-School Curriculum in 1998 (Kementerian Pendedikan Malaysia. Pusat Perkembangan Kurikulum, 1997). It was later introduced as one of the pedagogical models during in service courses for the revised common syllabus for all Malaysian schools beginning with the 13 and 16 years old students (Kementerian Pendedikan Malaysia. Pusat Perkembangan Kurikulum, 2007). Teachers were expected to teach the language using the suggested multiple intelligences approaches in their classes.

\section{REVIEW OF LiterATURE}

${ }^{*}$ Corresponding author 
Reese (2002) rightly argued that there is no "right" or "wrong" way to learn and there is no "good or bad" learning style. What matters most is what works for an individual learner. A student who has found his own learning styles that best fits his or her own intelligences has found the "right" way to learn. This is an argument that both practitioners and learners should agree on. Most often in traditional schools the opportunity to use these multiple intelligences effectively is lacking. Armstrong (cited in Fogarty \& Bellanca, 1995) lamented that schools have become 'worksheet wastelands' that are saturated with paper and pencil tasks.

The theory of multiple intelligences formulated by Gardner (1983) has great potential in revolutionizing our common concept of human capabilities (Christison, 1996). Fernie (cited in Fogarty \& Bellanca, 1995) added that his ideas were also based on his vast experiences in synthesizing knowledge beyond conventions and also based on empirical evidences from his Project Zero. This project recorded child development in a learning environment that caters to multiple intelligences over a period of time with emphasis to improve on techniques and strategies used in the classroom (Fogarty \& Bellanca, 1995). Only the first eight intelligences are considered for the purpose of this study since they are the currently popular ones. There are many definitions of the eight intelligences given by proponents of the theory. Here, the ones stated by Nolen (2003) are taken as reference for our deliberation.

\section{A. Verbal/Linguistic Intelligence}

This intelligence involves those with the mastery of language and they have the tendency to think in words and are highly skilled listeners. They are better memorizers of information and they enjoy storytelling and jokes. Their linguistic intelligences enable them to concentrate on grammar and vocabulary and they are efficient explainers, persuaders or entertainers. Teachers can give tasks on writing, reading and presenting oral reports about various aspects of their lives.

\section{B. Logical/Mathematical Intelligence}

This intelligence consists of the ability to detect patterns, reason deductively, and think logically. It is noted that they are usually the ones who do well in traditional classrooms because they are able to follow logical sequencing from the teaching. This intelligence often shows up early in life like savants who greatly gifted in calculations.

\section{Visual/Spatial Intelligence}

Having these intelligences would enable one to manipulate and create mental images in order to solve problems. They perceive the visual world accurately, perform transformations and modifications on their perceptions, and are able to recreate them in the absence of any physical stimuli. Teachers should consider using pictures or photographs, films, diagrams and other visuals.

\section{Bodily/Kinesthetic Intelligence}

We can observe people with this intelligent quite commonly because they use their body in very expressive and skillful ways for a distinct purpose. They are able to understand the world through their own body. They display very fine motor skills of their fingers and hands and the overall control of their body movements. They are also characterized with the ability to manipulate objects and to carry out precise and delicate movements. Kinesthetic is the ability to act gracefully and to apprehend the actions of other people or objects directly. They are, therefore, good in the performing arts with the ability to capture emotions through their body movements. Teaching entails the use of manipulative and physical movement since they like to touch things in order to learn and are often restless. Learning tools should be used to accommodate their 'busy' hands.

\section{E. Musical/Rhythmic Intelligence}

Those individuals with high musical intelligence use sound to the fullest extent. They understand well, the pitch, rhythm and timbre of music and can convey their emotions through it. Most people discover this intelligence at an early age. They are usually able to read music, critique performances and use musical-critical categories. Though often neglected in our culture and especially formal education, they can act as a way of capturing feelings, of knowing and understanding feelings, which is also important in education. It is also tied to other intelligences because it contains elements of ratio and regularity, which are also representative of mathematical reasoning.

\section{F. Interpersonal Intelligence}

An individual's sense of self, which consists of personal feelings and aspirations and their special responses to others, can also impact on the way a person learns. The interpersonal intelligence is the ability to understand, perceive and discriminate the moods, feelings, motives and intelligences of others. Those most often with such intelligence are: teachers, politicians, religious leaders, salesman, skilled parents, therapists or counselors. The learning and the use of a culture's symbolism can help develop this intelligent. It is mostly intrinsic to the individual and does not require much from others. Observation and the experience are the most suitable tools to improve this intelligence.

\section{G. Intrapersonal Intelligence}

Those who display intrapersonal intelligence are often imaginative, original, patient, disciplined, motivated and have a great deal of self-respect. They developed it from internal sources from within the person. In class, they need as much 
praise as they can get. Its development depends on how the learner wishes to use it. Teachers must think about 'imagination' exercises that could reveal their inner thoughts, reflections and feelings. Long-term projects could also be useful in that they strengthen their abilities to be patient and follow procedure. They are able to see what needs to be done in their minds to eventually make it happen.

\section{H. Naturalistic Intelligence}

Like the personal intelligences, naturalists could also benefit from observation and experience. It involves the ability to understand the nature's symbols and to respect the delicate balance of nature that has allowed us to live. They genuinely appreciate the intertwining of natural forces. They consider the future of the world first and are very much concerned and alarmed at the destruction and disruption of our planet. They often show expertise in the recognition and classification of plants and animals since they are a natural part of the environment. These children benefit a lot from learning outdoors in activities like: observing nature, labeling and mounting specimens, noticing changes in the environment, sorting articles for nature, nature hike or field trips or caring for pets. They are very comfortable with hands-on activities that involve natural objects.

We may be able to sense what our intelligences are and have within ourselves the capacity to activate them but we may not know how to use them effectively. Thus, according to Nolen (2003), the theory requires teachers to adjust their instructional strategies towards meeting the students' individual needs. This will not only activate their learning but may even help them to discover how to do it effectively.

Many studies were carried out by researchers on the efficacy of using multiple intelligences activities to assist learning the English language. When reading comprehension skills of fourth grade students in an American metropolitan city were found to be deficient, Gaines and Lehmann (2002) reported that multiple intelligences strategies as intervention had improved the situation. Furthermore, Reidel et al. (2003) had similar findings in a study done in an Illinois elementary school where there was an increase in reading comprehension and skill mastery that built a stronger, more confident and motivated reader. Shah and Thomas (2002) studied a 12-week program to improve spelling through multiple intelligences strategies. The result was an increase in the retention of high spelling frequency words.

\section{Research Questions}

Many studies have revealed that multiple intelligences play an important role in the learning process. Thus, the purpose of this research was to investigate the relationship between students' strengths in multiple intelligences and achievement in learning English. More specifically, the study sought to answer the following research questions:

1. What is the relationship between students' strengths in each of their multiple intelligences and their achievement in learning the English language?

2. Do students in the Arts and Science streams differ in the correlation of their strengths in multiple intelligences and their English language achievement?

3. Which of the multiple intelligences predicts the strongest influence on the students' English language achievement?

4. What are the differences between Science and Art streams students in their multiple intelligences strengths that predict the strongest influence on English language achievement?

\section{METHODOLOGY}

This research is exploratory in nature and as such as no attempt has been made to formulate hypothesis for the study. Both descriptive and inferential methods are used for the analysis. They include correlation and multiple regressions. These methods are to explain the research questions about the relationship between students' strength in each of their multiple intelligences and their achievement in learning the English language.

The variables consist of the multiple intelligences test scores and the students' English language final exam results. They are selected based on a theoretical basis and from personal experience and thus would make the interpretation of the results more meaningful (Gay \& Airasian, 2009).

The target population for this study was Form 4 (16 years old) male secondary school students from an urban background. 120 Form 4 male students were randomly selected as the participants of this study. They consisted of 60 Form 4 Science students from three classes and another 60 Form 4 Art students from three other classes. These boys were of mixed abilities as far as their competency in the English language was concerned.

Firstly, the test was administered to all the Science and Art stream students. This would avoid the irksome situation of having some students feeling left out from the study. In any case, all of them would benefit from the knowledge of their own multiple intelligences profile.

Then, the required number of 60 students from each stream was chosen at random from the number taken. The randomly selected ones were then numbered sequentially for easier data analysis. This method was used because of the relatively small and manageable size of the sampling set for the study.

\section{A. Multiple Intelligences Test}

A multiple intelligent test adapted from an inventory designed by the Learning Disabilities Resources Community (LRDC), Ontario, Canada was used to determine the students' strength in their multiple intelligences (see the 
Appendix). The organization could be contacted at: The Adaptive Technology Resource Centre (ATRK), University of Toronto, 130, St. George Street, First Floor, Toronto, Ontario, Canada M5S 3H1.

The instrument consisted of 80 items, 10 for each of the eight intelligences. Each item is a description of one of the multiple intelligences that is manifested in their behaviors, feelings and attitudes. For each item, the subjects were instructed to choose from a 5-level Likert scale. They had used this scale to indicate their level of agreement with the item concerned. As there are 10 items with a maximum of 5 marks for each item, the total score for each set of intelligence is 50 . The intelligence with the highest total represents the student's strongest intelligence. This produced a multiple intelligences profile for each student.

Work then commenced on ensuring that the translated instrument was reliable. This was carried out through back-toback translation and a pilot test on 35 students not from the chosen sample. Reliability analysis was carried out using the 'Cronbach Alpha' method. The test was based on an alpha limit higher than 0.6 to indicate reliability. All the collected data for the research was analyzed using the 'Statistical Package for Social Sciences' 11.0 versions (SPSS 11.0). It was used for both the instrument pilot testing stage and the actual data collection.

\section{B. English Language Achievement Test}

The students' Form 4 Final English Language Examination results were used for the achievement scores. The test scores represented each student's summative performance in the English language subject for that year. It showed the range of achievement between those who excelled in the language and those who did not. The exam paper was based on the format of the 1119 English language $1 \& 2$ SPM Examination papers used by the Examination Syndicate of the Malaysian Ministry of Education. It is designed to test the students' ability in using the English language in the productive skills of reading and writing. It is the content and subscription to the Malaysian Educational curriculum specifically through the Secondary Level English Language Syllabus.

\section{FINDINGS}

A description of the respondents' multiple intelligences was made using descriptive analysis involving the use of means and standard of deviations. This can be seen in table 1 below. This statistical examination only looked at the multiple intelligences which at this point are not yet seen in relation to their English language achievement. It is noted that for easy reference, the acronyms (in brackets) after each word or phrase will be used henceforth in the later tables.

The analysis of data reveals that respondents from both streams have the highest disposition for the interpersonal intelligence (Mean = 3.38). This is followed by their intelligences in the logical $/$ mathematical $($ Mean = 3.35); intrapersonal $($ Mean $=3.24)$; visual/spatial (Mean = 3.08) and the naturalistic (Mean =3.05).

On the other hand, the students' multiple intelligences that were less used by the respondents are the musical/rhythmic $($ Mean $=2.99)$, bodily/kinesthetic $($ Mean $=2.98)$ and the verbal/linguistic $($ Mean $=2.97)$.

TABLE 1

MEAN SCORES AND STANDARD DEVIATIONS OF RESPONDENTS MULTIPLE INTELLIGENCES

\begin{tabular}{|c|c|c|c|c|c|c|}
\hline \multirow{3}{*}{ Multiple Intelligences } & \multicolumn{2}{|c|}{ Science \& Arts } & \multicolumn{2}{|c|}{ Science } & \multicolumn{2}{|l|}{ Arts } \\
\hline & \multicolumn{2}{|c|}{$(\mathrm{n}=120)$} & \multicolumn{2}{|c|}{$(\mathrm{n}=60)$} & \multicolumn{2}{|c|}{$(\mathrm{n}=60)$} \\
\hline & Mean & SD & Mean & SD & Mean & SD \\
\hline Verbal/Linguistic (VL) & 2.97 & 0.63 & 2.81 & 0.57 & 3.14 & 0.65 \\
\hline Logical/Mathematical(LM) & 3.35 & 0.71 & 3.31 & 0.65 & 3.38 & 0.78 \\
\hline Visual/Spatial (VS) & 3.08 & 0.61 & 2.94 & 0.53 & 3.22 & 0.66 \\
\hline Bodily/Kinesthetic (BK) & 2.98 & 0.66 & 2.82 & 0.53 & 3.14 & 0.74 \\
\hline Musical/Rhythmic (MR) & 2.99 & 0.73 & 2.87 & 0.69 & 3.1 & 0.76 \\
\hline Interpersonal (INTERP) & 3.38 & 0.63 & 3.37 & 0.54 & 3.39 & 0.72 \\
\hline Intrapersonal (INTRAP) & 3.24 & 0.68 & 3.14 & 0.65 & 3.33 & 0.69 \\
\hline Naturalistic (NAT) & 3.05 & 0.84 & 2.81 & 0.79 & 3.30 & 0.84 \\
\hline
\end{tabular}

A similar distribution pattern could be seen for both the Science and Arts stream students. However, the total mean scores obtained from the Art students for each sub-scale of multiple intelligences shows a more definitive or consistent pattern as compared to the Science stream students. Therefore, to identify the differences in mean scores of the multiple intelligences statistically, a t-test for comparative analysis was carried out. The analyzed data for this purpose can be seen in table 2 below.

The analysis of $\mathrm{t}$-test reveals that there is a significant difference for the multiple intelligences of verbal/linguistic $(\mathrm{t}=$ -2.99; $\mathrm{p}=0.003)$; visual/spatial $(\mathrm{t}=-2.51 ; \mathrm{p}=0.0013)$, bodily/kinesthetic $(\mathrm{t}=-2.67 ; \mathrm{p}=0.0009)$ and naturalistic $(\mathrm{t}=-$ $3.24 ; \mathrm{p}=0.002$ ). Conversely, an analysis of the data shows that the multiple intelligences of logical $/ \mathrm{mathematical}$, musical/rhythmic, interpersonal and intrapersonal have no significant differences at the level $\mathrm{p}<0.05$.

The below results explain that the mean scores for the multiple intelligences of verbal/linguistic, visual/spatial, bodily/kinesthetic and naturalistic are higher for the Art students than for the Science students. In other words, the Art stream students have a stronger disposition for this multiple intelligences than their Science counterparts. Nevertheless, for the multiple intelligences of logical/mathematical, musical/rhythmic, interpersonal and intrapersonal, the statistical analysis proves that both Science and Art stream students have similar low degree of use for them. 
TABLE 2

STATISTICAL DATA FOR T-TEST TO SEE THE DIFFERENCES IN THE MEAN SCORESOF THE MULTIPLE INTELLIGENCES BETWEEN SCIENCE AND ART STUDENTS

\begin{tabular}{|c|c|c|c|c|c|c|c|}
\hline \multirow{3}{*}{$\begin{array}{l}\text { Multiple } \\
\text { Intelligences }\end{array}$} & \multicolumn{2}{|c|}{ Science \& Arts } & \multirow{2}{*}{\multicolumn{2}{|c|}{$\begin{array}{l}\text { Science } \\
(\mathrm{n}=60)\end{array}$}} & \multirow{3}{*}{$\mathrm{t}$ value } & \multirow{3}{*}{ Sig. } & \multirow{3}{*}{$F$ value } \\
\hline & \multicolumn{2}{|c|}{$(\mathrm{n}=120)$} & & & & & \\
\hline & Mean & SD & Mean & SD & & & \\
\hline $\mathrm{VL}$ & 2.81 & 0.56 & 3.14 & 0.65 & $-2.99 *$ & 0.003 & 1.39 \\
\hline LM & 3.31 & 0.65 & 3.38 & 0.78 & -0.49 & 0.622 & $4.11 *$ \\
\hline VS & 2.94 & 0.53 & 3.22 & 0.66 & $-2.51 *$ & 0.013 & $6.04 *$ \\
\hline BK & 2.82 & 0.53 & 3.13 & 0.66 & $-2.67 *$ & 0.009 & $9.39 *$ \\
\hline MR & 2.87 & 0.69 & 3.11 & 0.75 & -1.75 & 0.082 & 1.10 \\
\hline INTERP & 3.37 & 0.53 & 3.38 & 0.72 & -0.129 & 0.898 & $7.83^{*}$ \\
\hline INTRAP & 3.14 & 0.65 & 3.33 & 0.69 & -1.47 & 0.142 & 0.697 \\
\hline NAT & 2.81 & 6.79 & 3.3 & 0.83 & $-3.24 *$ & 0.002 & 1.56 \\
\hline
\end{tabular}

To answer the first research question, the relationship between the variables are analyzed by using Pearson Correlation while the strength of the relationships are interpreted based on Gay and Airasian (2009), where a correlation of 0.8 and above is interpreted as 'very high', 0.6 to 0.8 as 'high', 0.4 to 0.6 as 'average' and less than 0.4 as 'weak' respectively.

TABLE 3

PEARSON CORRELATION ANALYSIS ON STUDENTS MULTIPLE INTELLIGENCES AND ENGLISH LANGUAGE ACHIEVEMENT

\begin{tabular}{|c|c|c|c|c|c|c|c|c|c|}
\hline & VL & LM & VS & BK & MR & INTER & INTRA & NAT & ACHV \\
\hline VL & - & & & & & & & & \\
\hline LM & $0.652 *$ & - & & & & & & & \\
\hline VS & $0.447 *$ & $0.440 *$ & - & & & & & & \\
\hline BK & $0.329 *$ & $0.359 *$ & $0.567 *$ & - & & & & & \\
\hline MR & $0.420 *$ & $0.303^{*}$ & $0.492 *$ & $0.461 *$ & - & & & & \\
\hline INTER & $0.675 *$ & $0.605^{*}$ & $0.469 *$ & $0.332 *$ & $0.421^{*}$ & - & & & \\
\hline INTRA & $0.511 *$ & $0.449^{*}$ & $0.358 *$ & $0.293^{*}$ & $0.309^{*}$ & $0.537^{*}$ & - & & \\
\hline NAT & $0.677^{*}$ & $0.623^{*}$ & $0.546^{*}$ & $0.472 *$ & $0.445^{*}$ & $0.637^{*}$ & $0.568^{*}$ & - & \\
\hline $\begin{array}{l}\text { Achievement } \\
\text { (ACHV) }\end{array}$ & $-0.222 *$ & -0.015 & $-0.305^{*}$ & $-0.249 *$ & $-0.244^{*}$ & -0.018 & -0.112 & $-0.341 *$ & - \\
\hline
\end{tabular}

From the table above, it could be seen that for all the students there are significant correlations between some of their multiple intelligences and English language achievement. However, these relationships are negatively correlated: verbal/linguistic $(\mathrm{r}=-0.222 ; \mathrm{p}<0.005)$, visual/spatial $(\mathrm{r}=-0.305 ; \mathrm{p}<0.05)$, bodily/kinesthetic $(\mathrm{r}=-0.249 ; \mathrm{p}<0.05)$, musical/rhythmic $(r=-0.244 ; \mathrm{p}<0.05)$, and naturalistic intelligence $(\mathrm{r}=-0.341 ; \mathrm{p}<0.05)$. Looking at the strengths among these relationships, their correlation coefficient values ( $\mathrm{r}$ is less than 0.4 ) are all on the weak side. Nevertheless, the multiple intelligences for logical/mathematical, interpersonal and intrapersonal do not show any significant relationship with language achievement.

The second research question requires a comparative analysis of the correlation values for the variables in both Science and Art streams. Table 4 below helps with this investigation.

As indicated in table 4, for the Science stream students, only their logical/mathematical intelligence $(r=0.268 ; \mathrm{p}<$ 0.05) have a significant positive relationship with their achievement in the language. However, the correlation coefficient value is small ( $\mathrm{r}$ is less than 0.4 ) and thus it shows only a weak relationship. At the same time, it can be seen that in the Science stream, all the other multiple intelligences do not show a significant relationship with their English language achievement. 
TABLE 4

PEARSON COEFFICIENT ANALYSIS ON THE COMPARISON BETWEEN SCIENCE AND ART STUDENTS' CORRELATION OF MULTIPLE INTELLIGENCES AND ENGLISH LANGUAGE ACHIEVEMENT

\begin{tabular}{|l|c|c|c|c|c|c|c|c|c|c|}
\hline & & VL & LM & VS & BK & MR & INTER & INTRA & NAT & ACHV \\
\hline \multirow{3}{*}{ VL } & Sc. & - & & & & & & & & \\
\hline & Art & - & & & & & & & & \\
\hline \multirow{3}{*}{ LM } & Sc. & $0.521^{*}$ & - & & & & & & & \\
\hline & Art & $0.770^{*}$ & - & & & & & & & \\
\hline \multirow{3}{*}{ VS } & Sc. & 0.142 & 0.136 & - & & & & & & \\
\hline & Art & $0.603^{*}$ & $0.649^{*}$ & - & & & & & & \\
\hline \multirow{3}{*}{ BK } & Sc. & 0.100 & 0.006 & $0.324^{*}$ & - & & & & & \\
\hline & Art & $0.401^{*}$ & $0.576^{*}$ & $0.670^{*}$ & - & & & & & \\
\hline \multirow{3}{*}{ MR } & Sc. & $0.321^{*}$ & 0.069 & $0.259^{*}$ & $0.308^{*}$ & - & & & & \\
\hline & Art & $0.457^{*}$ & $0.479^{*}$ & $0.635^{*}$ & $0.535^{*}$ & - & & & & \\
\hline \multirow{3}{*}{ INTER } & Sc. & $0.501^{*}$ & $0.450^{*}$ & 0.178 & 0.077 & $0.258^{*}$ & - & & & \\
\hline & Art & $0.826^{*}$ & $0.704^{*}$ & $0.658^{*}$ & $0.479^{*}$ & $0.542^{*}$ & - & & & \\
INTRA & Sc. & $0.302^{*}$ & $0.315^{*}$ & 0.075 & 0.152 & 0.042 & 0.244 & - & & \\
\hline & Art & $0.658^{*}$ & $0.553^{*}$ & $0.540^{*}$ & $0.355^{*}$ & $0.511^{*}$ & $0.753^{*}$ & - & & \\
\hline \multirow{3}{*}{ NAT } & Sc. & $0.573^{*}$ & 0.534 & $0.343^{*}$ & 0.251 & $0.269^{*}$ & $0.509^{*}$ & $0.445^{*}$ & - & \\
\hline & Art & $0.715^{*}$ & $0.720^{*}$ & $0.649^{*}$ & $0.564^{*}$ & $0.556^{*}$ & $0.776^{*}$ & $0.659^{*}$ & - & \\
\hline \multirow{3}{*}{ ACHV } & Sc. & 0.152 & $0.268^{*}$ & -0.083 & 0.006 & -0.132 & 0.072 & 0.187 & -0.010 & - \\
\cline { 2 - 11 } & Art & -0.154 & -0.156 & $-0.323^{*}$ & -0.172 & $0.261^{*}$ & -0.081 & -0.082 & $-0.371^{*}$ & - \\
\hline
\end{tabular}

On the other hand, for the Art stream students, the analysis shows that their multiple intelligences for visual/spatial (r $=-0.323 ; \mathrm{p}<0.05) ;$ musical/rhythmic $(\mathrm{r}=-0.261 ; \mathrm{p}<0.05)$ and naturalistic $(\mathrm{r}=-0.371 ; \mathrm{p}<0.05)$ have significant relationships but are negatively correlated with the respondents language achievement. In addition, it could be seen that these relations have very low correlation coefficient ( $\mathrm{r}$ is less than 0.4) and are, therefore, rather weak.

Regarding the third research question, the strengths in the relationship between the students multiple intelligences and their English language achievement could be predicted more accurately by using the multiple regression analysis as can be seen in the table 5 below.

The research findings show that as much as $29.2 \%$ of the variants were contributed by all the 8 multiple intelligences towards the variable for language achievement. It is also revealed that the multiple intelligences for verbal/linguistic $(\beta$ $=-0.26)$, logical $/$ mathematical $(\beta=-0.33)$, musical $/$ rhythmic $(\beta=-0.08)$, naturalistic $(\beta=-0.47)$, and interpersonal $(\beta=-$ 0.37 ) have significant influences on language achievement.

Nevertheless, the analysis reveals that interpersonal intelligence predicts the strongest positive influence on language achievement as compared to logical/mathematical intelligence. At the same time, it can be seen that their naturalistic intelligence predicts the strongest negative influence on achievement as compared to verbal/linguistic and musical/rhythmic intelligences.

TABLE 5

MULTIPLE REGRESSION ANALYSIS ON THE INFLUENCE OF STUDENTS' MULTIPLE INTELLIGENCES ON ENGLISH LANGUAGE ACHIEVEMENT

\begin{tabular}{|l|l|l|l|l|}
\hline Variables & B & $\beta$ & T value & Sig. \\
\hline (Constant) & 64.44 & - & 4.34 & 0.00 \\
\hline VL & -10.59 & -0.26 & -2.00 & $0.04^{*}$ \\
\hline LM & 11.96 & 0.33 & 2.83 & $0.00^{*}$ \\
\hline VS & -8.87 & -0.21 & -1.89 & 0.06 \\
\hline BK & -1.87 & -0.04 & -0.45 & 0.65 \\
\hline MR & -2.73 & -0.08 & -0.77 & 0.44 \\
\hline INTER & 15.42 & 0.37 & 3.06 & $0.00^{*}$ \\
\hline INTRA & 1.89 & 0.05 & 6.48 & 0.63 \\
\hline NAT & -14.49 & -0.47 & -3.58 & $0.00^{*}$ \\
\hline R= 0.541; R square $=0.292 ;$ & Adj. R square $=0.24$ \\
\hline
\end{tabular}

To answer the fourth research question, a multiple regression analysis was carried out on the data variables of both streams which is displayed in table 6 below. 
TABLE 6

MULTIPLE REGRESSION ANALYSIS ON THE INFLUENCE OF STUDENTS' MULTIPLE INTELLIGENCES ON ENGLISH LANGUAGE ACHIEVEMENT: COMPARISON BETWEEN SCIENCE AND ART STUDENTS

\begin{tabular}{|c|c|c|c|c|c|c|}
\hline \multirow[t]{2}{*}{ Variables } & \multicolumn{3}{|c|}{ Science Stream } & \multicolumn{3}{|c|}{ Art stream } \\
\hline & $\mathrm{B}$ & BETA & T Value & $\mathrm{B}$ & Beta & $\mathrm{T}$ Value \\
\hline (Constant) & 39.46 & - & 1.981 & 41.42 & - & 4.027 \\
\hline VL & 4.23 & 0.157 & 0.898 & -3.25 & -0.139 & -0.588 \\
\hline LM & 7.33 & 0.31 & 1.891 & 3.88 & 0.197 & 0.951 \\
\hline VS & -1.38 & -0.048 & -0.334 & -9.25 & -0.400 & $-2.081 *$ \\
\hline $\mathrm{BK}$ & 2.96 & 0.102 & 0.717 & 3.39 & 0.164 & 0.972 \\
\hline MR & -3.27 & -0.148 & -1.015 & -1.77 & -0.088 & -0.561 \\
\hline INTER & 0.37 & 0.013 & 0.082 & 15.97 & 0.758 & $2.984 *$ \\
\hline INTRA & 4.02 & 0.171 & 1.174 & -1.95 & -0.089 & -0.492 \\
\hline NAT & -6.19 & -0.319 & -1.666 & -13.27 & -0.727 & $-3.513 *$ \\
\hline \multicolumn{4}{|c|}{$\begin{array}{l}\mathrm{R}=0.409 \\
\mathrm{R}^{2}=0.167 \\
\text { Adj. } \mathrm{R}^{2}=0.037\end{array}$} & \multicolumn{3}{|c|}{$\begin{array}{l}\mathrm{R}=0.582 \\
\mathrm{R}^{2}=0.339 \\
\text { Adj. } \mathrm{R}^{2}=0.235\end{array}$} \\
\hline
\end{tabular}

The analysis shows that for the Science stream students, there is not even one of their intelligences which is significantly influential on the respondents' English language achievement. In contrast, the students from the Art stream have three multiple intelligences that are significantly influential on their language achievement. They are the multiple intelligences of visual/spatial $(\beta=-0.400)$, interpersonal $(\beta=-0.758)$, and naturalistic $(\beta=-0.727)$. Of the three multiple intelligences, the interpersonal predicts the strongest positive influence on the respondents' language achievement. It is also noted that the naturalistic intelligence has the strongest negative predictor on the Art students' language achievement.

\section{DisCUSSION}

The four research questions have resulted in the revelation of the following findings:

Generally, for all the students it is discovered that there are some significant negative correlations between students' multiple intelligences and their English language achievement. They are the multiple intelligences of verbal/linguistics, visual/spatial, bodily/kinesthetic, musical/rhythmic, and naturalistic intelligence. The strengths between these relationships are all quite weak. On the other hand, the multiple intelligences for logical/mathematical, interpersonal and intrapersonal do not show any significant relationship with language achievement.

For the Science stream students, only their logical/mathematical intelligence has a significant positive relationship with their achievement in the language. Nonetheless, the relationship is a weak one. All the other multiple intelligences do not show a significant relationship with their English language achievement. It is, however, different for the Art stream students. Their strengths in multiple intelligences for visual/spatial, musical/rhythmic, and naturalistic have significant but negative and weak relationship with the respondents' language achievement.

All the eight multiple intelligences were shown to contribute the same predicted influence towards the students' language achievement. The interpersonal intelligence shows the strongest significant positive influence on language achievement followed by logical/mathematical intelligence. Whereas naturalistic intelligence shows the strongest significant but negative influence on language achievement, followed by the verbal/linguistic and musical/rhythmic intelligences.

For the Science stream students, there is not even one of their multiple intelligences that are predicted to have a significant influence on the respondents' English language achievement. This is in contrast to the Art stream students, where their interpersonal intelligence is the only significant predictor with the strongest positive influence on the respondents' language achievement. Yet, their naturalistic and visual/spatial intelligences predict significantly negative influence on their language achievement.

\section{CONCLUSION}

This study investigates the relationship between the students' strength in multiple intelligences and their achievement in the English language. What the results can conclude for this study is that in an environment where multiple intelligences may not have a strong presence in the classroom practice, both learners and practitioners may be unable to gain the best results. In a nutshell, this study could help teachers to consider how best to teach English language with multiple intelligences in mind. They can organize the class activities in such a way to develop all students multiple intelligences. It could also encourage the learners to use multiple intelligences to learn English language as they become properly aware of the issue. Having adjusted at utilizing their intelligences efficiently through practice and experience, the learners can easily learn autonomously.

\section{APPENDIX LRDC MULTIPLE INTELLIGENCES TEST}

What are my learning strengths? 
Research shows that all human beings have at least eight different types of intelligences. Depending on your background and age, some intelligences are more developed than others. This activity will help you find out what your strengths are. Knowing this, you can work to strengthen the other intelligences that you do not use as often.

\begin{tabular}{|c|c|}
\hline Verbal/Linguistic Intelligence & Logical/Mathematical intelligence \\
\hline $\begin{array}{l}\text { I enjoy telling stories and jokes } \\
\text { I have a good memory for trivia } \\
\text { I enjoy word games (e.g. Scrabble \& puzzles) } \\
\text { I read books just for fun } \\
\text { I am a good speller (most of the time) } \\
\text { In an argument I tent to use put- downs or sarcasm } \\
\text { I like talking and writing about my ideas } \\
\text { If I have to memorize something I create a rhyme or saying } \\
\text { to help me remember. } \\
\text { If something breaks and won't work, I read the instruction } \\
\text { book first } \\
\text { library research }\end{array}$ & $\begin{array}{l}\text { I really enjoy math class } \\
\text { I like logical math puzzles or brain teasers } \\
\text { I find solving math problems to be fun } \\
\text { Iogical order } \\
\text { If I have to memorize something I tend to place events in a } \\
\text { I like to find out how things work } \\
\text { I enjoy computer and any math games } \\
\text { I love playing chess, checkers or Monopoly } \\
\text { In In an argument, I try to find a fair and logical solution } \\
\text { try to figure out how it works } \\
\text { graphs }\end{array}$ \\
\hline
\end{tabular}

\begin{tabular}{|c|c|}
\hline Visual/Spatial Intelligence & Bodily/Kinesthetic Intelligence \\
\hline $\begin{array}{l}\text { I prefer a map to written directions } \\
\text { I day dream a lot } \\
\text { I enjoys hobbies such as photography } \\
\text { I like to draw and create } \\
\text { If I have to memorize something I draw a diagram to help } \\
\text { me remember } \\
\text { I like to doodle on paper whenever I can } \\
\text { In__ In a magazine, I prefer looking at the pictures rather than } \\
\text { reading the next } \\
\text { In an argument I try to keep my distance, keep silence or } \\
\text { visualize some solution } \\
\text { If something breaks and won't work I tend to study the } \\
\text { diagram of how it works } \\
\text { For a group presentation I prefer to draw all the pictures }\end{array}$ & $\begin{array}{l}\text { My favorite class is gym since I like sports } \\
\text { I I enjoys activities such as woodworking, sewing and } \\
\text { building models } \\
\text { When looking at things, I like touching them } \\
\text { I have trouble sitting still for any length of time } \\
\text { I use a lot of body movements when talking } \\
\text { If I have to memorize something I write it out a number of } \\
\text { times until I know it } \\
\text { I tend to tap my fingers or play with my pencil during class } \\
\text { In a argument I tend to strike out and hit or run away } \\
\text { I something breaks and won't work I tend to play with the } \\
\text { pieces to try to fit them together } \\
\text { For a group presentation I prefer to move the props around, } \\
\text { hold things up or build a model }\end{array}$ \\
\hline
\end{tabular}

\begin{tabular}{|c|c|}
\hline Musical/Rhythmic Intelligence & Interpersonal Intelligence \\
\hline $\begin{array}{l}\text { I enjoy listening to CD's and the radio } \\
\text { I tend to hum to myself when working } \\
\text { I like to sing } \\
\text { I play a musical instrument quite well } \\
\text { I like to have music playing when doing homework or } \\
\text { studying } \\
\text { about the event } \\
\text { If I an argument I tend to shout or punch or move in some } \\
\text { sort of rhythm } \\
\text { I can remember the melodies of many songs } \\
\text { If something breaks and won't work I tent to tap my } \\
\text { fingers to a beat while I figure it out } \\
\text { For a group presentation I prefer to put new words to a } \\
\text { popular tune or use music }\end{array}$ & $\begin{array}{l}\text { I get along well with others } \\
\text { I like to belong to clubs and organizations } \\
\text { I have several very close friends } \\
\text { I like helping teach other students } \\
\text { I like working with others in groups } \\
\text { Friends ask my advice because I seem to be a natural leader } \\
\text { If I have to memorize something I ask someone to quiz me } \\
\text { to see if I know it } \\
\text { In an argument I tend ask a friend or some person in } \\
\text { authority for help } \\
\text { If something breaks and won't work I try to find someone } \\
\text { who can help me } \\
\text { For a group presentation I like to help organize the group's } \\
\text { efforts }\end{array}$ \\
\hline
\end{tabular}

\begin{tabular}{|c|c|}
\hline Intrapersonal Intelligence & Naturalist Intelligence \\
\hline $\begin{array}{l}\text { I like to work alone without anyone bothering me } \\
\text { I like to keep a diary } \\
\text { I like myself (most of the time) } \\
\text { I don't like crowds } \\
\text { I know what I am good at and what I am week at } \\
\text { I I find that I am strong-willed, independent and don't } \\
\text { follow the crowds } \\
\text { and feel I have to memorize something I tend to close my eyes } \\
\text { In an argument I will usually walk away until I calm down } \\
\text { If something breaks and won't work, I wonder if it's worth } \\
\text { fixing up } \\
\text { For a group presentation I like to contribute something that } \\
\text { is uniquely mine, often based on how I feel }\end{array}$ & $\begin{array}{l}\text { I I am keenly aware of my surroundings and of what goes on } \\
\text { around me } \\
\text { and flowers } \\
\text { I l enjoy gardening } \\
\text { I I like to collect things (e.g., rocks, sports cards, stamps, etc) } \\
\text { and enjoy nature } \\
\text { As an adult, I think I would like to get away from the city } \\
\text { categories } \\
\text { environment, such as to memorize something, I tend to organize it into } \\
\text { I I an argument I tend to compare my opponent to someone or } \\
\text { something I have read or heard about and react accordingly } \\
\text { I s something breaks down, I look around me to try and see } \\
\text { what I can find to fix the problem } \\
\text { For a group presentation I prefer to organize and classify the } \\
\text { information into categories so it makes sense }\end{array}$ \\
\hline
\end{tabular}




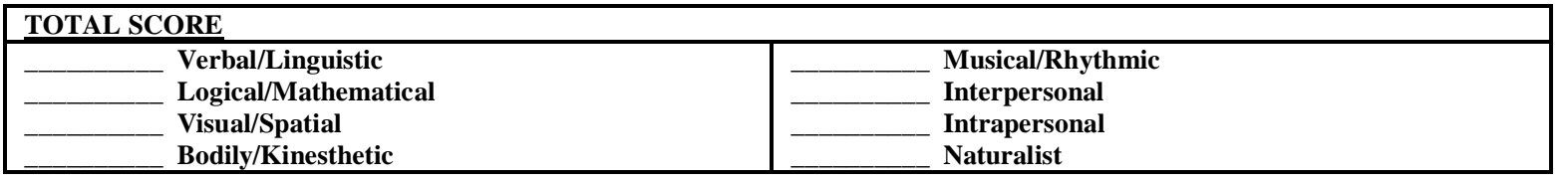

\section{ACKNOWLEDGEMENT}

This work was supported in part by the fellowship scheme of University of Science Malaysia.

\section{REFERENCES}

[1] Christison, M. (1996). Teaching and learning languages through multiple intelligences. TESOL Journal, 6(1), 10-14.

[2] Ebeling, D. (2000). Adapting your teaching to any learning style. Multiple intelligence Phi Delta Kappan, 82(3), $247-248$.

[3] Fogarty, R. \& Bellanca, J. (1995). Multiple intelligences: A collection. Illinois: IRI/SkyLight Training and Publishing, Inc.

[4] Gaines, D., \& Lehmann, D. (2002). Improving student performance in reading comprehension through the use of multiple intelligences. ERIC documents reproduction service no: ED467515. http://eric.ed.gov/PDFS/ED467515.pdf (accessed 25/7/2011).

[5] Gardner, H. (1983). Frames of mind: The theory of multiple intelligences, New York: Basic Books.

[6] Gay, L. R. \& Airasian, P. W. (2009). Educational research: competencies for analysis and application. USA: Merrll Prentice Hall.

[7] Kementerian Pendidikan Malaysia. Pusat Perkembangan Kurikulum (1997). Smart-school conceptual blueprint. Kementerian Pendidikan Malaysia, Kuala Lumpur.

[8] Kementerian Pendidikan Malaysia. Pusat Perkembangan Kurikulum (2007). English language syllabus specification course module. Kementerian Pendidikan Malaysia, Kuala Lumpur.

[9] Lazear, D. (1994). Seven ways of teaching: The artistry of teaching with multiple intelligences. Melbourne: Hawaker Brownlow Education.

[10] Nolen, J. (2003). Multiple intelligences in the classroom. Education 124, 115-120.

[11] Reese, S. (2002). Understanding our differences. Techniques: Connecting Education and Careers, 77(1), 20-23.

[12] Reidel, J., Tomaszewski, T. \& Weaver, D. (2003). Improving student academic reading achievement through the use of Multiple intelligence teaching strategies. ERIC documents reproduction service no: ED479204. http://eric.ed.gov/PDFS/ED479204.pdf (accessed 15/8/2011).

[13] Shah, T. \& Thomas, A. (2002). Improving the spelling of high frequency words in daily writing through the use of multiple intelligence centers. ERIC documents reproduction service no: ED471069. http://eric.ed.gov/PDFS/ED471069.pdf (accessed 12/8/2011).

[14] The University of Toronto's Adaptive Technology Resource Center (2002). Learning disability resource community.

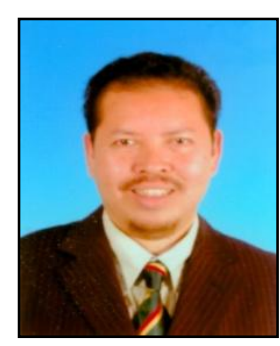

Majid Pour-Mohammadi was born in Rasht, Iran in 1971. He is currently doing his PhD studies in TESOL (Teaching English to Speakers of Other Languages) at University of Science Malaysia (USM), Malaysia. He received his MA in TEFL (Teaching English as a Foreign Language) from Shahid Chamran University of Ahvaz, Iran in 2001 and a BA in English Translation from Islamic Azad University of Rasht, Iran in 1999.

He has been a faculty member and lecturer at Islamic Azad University of Rasht, Iran since 2000. He was also the head of English Language Translation Department at Islamic Azad University of Rasht, Iran from 2006 to 2009. He has taught English courses at a number of nationwide and Islamic Azad universities in Guilan, Iran. His research interests are teaching methodology, ICT and research methodology in language learning and teaching. He has several published books as well as articles in national and international journals. For instance, Aghajanzade, G. \& Pour-Mohammadi, M. (2005). English reading passages for university students. Tehran: Alvandpouyan Publications.; Hayati, A. \& Pour-Mohammadi, M. (2005). A comparative study of using bilingual and monolingual dictionaries in reading comprehension of intermediate EFL students. The Reading Matrix. 5(2), 61-66.; Jafre, M., Pour-Mohammadi, M. \& Alzwari, H., EFL students' attitudes towards learning English language: The case of Libyan secondary school students, Asian Social Science, (be published in Feb. 2012).

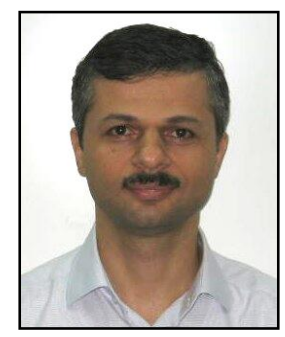

Mohamad Jafre Zainol Abidin was born in Malaysia in 1961. He received a PhD in ESP (English for Specific Purposes) from Keele University, UK in 1992, a MA in MEd (Master of Education) from the same university in 1987. He also received an Advanced Diploma in Applied Linguistics from University of Edinburgh, UK in 1989, and a BA in Arts with Education from University of Science Malaysia, Malaysia in 1985.

Dr Mohamad Jafre Zainol Abidin is currently the Programme Chairman for TESOL at the School of Educational Studies, University of Science Malaysia. He has been a teacher educator for the last 20 years. His research interest is in ICT and TESOL. He has published articles in national and international journals including: Jafre, M. Z. A, Rezaee, A. A., Abdullah, H. N. \& Singh, K. K. B. (2011). Learning styles and overall academic achievement in a specific educational system. International Journal of Humanities and Social Science. 1(10), 143-152. 
Khairul Anuar Bin Yang Ahmad received his Master of Education majoring in TESOL from the School of Educational Studies, University of Science Malaysia in 2010. As an English language teacher, he has been teaching for 5 years in secondary schools. His research interests are TESOL and ICT. 